\title{
Enej Silvij Piccolomini in sveti Maksim Grek - razumevanje humanističnega individuuma
}

\section{Neža Zajc*}

\section{LITERARNOZGODOVINSKE VZPOREDNICE (BIOGRAFSKA RAVEN)}

Enej Silvij Piccolomini je odraščal in se šolal v siensko-florentinskih šolah. ${ }^{1}$ Pozneje je navezal stike z Nikolajem Kuzanskim, ki je nekaj let pred Lorenzom Vallo že deloma razkril Konstantinovo »Darovnico ${ }^{2}$ To so bila težavna leta, ko si je bilo na podlagi omenjene besedilne kritike nujno izoblikovati humanistično presojo s širokim večstranskim pogledom na Cerkev, obenem pa se je od humanistov pričakovalo, da so odprti in odzivni tudi na različne možnosti kulturnih preobratov na ravni literarnega ustvarjanja. ${ }^{3}$ Osnovni sienski klasični študij z osnovami morale in didaktike (studium generale) je Piccolomini nadaljeval v Firencah, kjer so bili njegovi študijski prijatelji Andrea Biblia, Gregorio iz Spoleta, verjetno tudi učenjak Francesco Filelfo, ki je Eneja Silvija predstavil učiteljem Panormitanu (Niccolò de Tudeschi), Poggiu Braccioliniju, Leonardu Bruniju

* Inštitut za kulturno zgodovino ZRC SAZU, Novi trg 2, Ljubljana, neza.zajc@zrc-sazu.si

1 Biografija obeh obravnavanih avtorjev se omejuje na osvetlitev dogodkov, relevantnih za primerjalno študijo. Kjer ni drugače navedeno, so prevodi avtoričini.

2 Geanakoplos, Byzantine East and Latin West, 98.

3 Vse omenjeno, povezano z renesančno tekstno-filološko kritiko, ki je vplivala na drugačno presojo kanoničnih del, je veljalo tudi za izobrazbo Mihaela Trivolisa oziroma Maksima Greka; Garzaniti, „Svjaščennoe pisanie i auctoritates u Maksima Greka«, 33-35. 
in Guarinu Veronskemu. ${ }^{4}$ Po poglobitvi v latinsko slovnico in po navduševanju nad pesniki in govorniki se je Piccolomini leta 1425 preusmeril v študij civilnega prava. Sled tega se kaže tudi v njegovih pismih, ki so vključevala navezave na Gracijanovo zbirko kanonov ali Dekret (Decretum ali Concordia discordantum canonum). ${ }^{5}$ Njegov učitelj je bil Mariano Sozzini, ki ga je Enej občudoval in se vse življenje spominjal njegove predanosti humanizmu, njegove razgledanosti in govorniške sposobnosti. Vendar ga je morda prav širina učiteljevih pogledov in znanj vodila k ustvarjalni neizpolnjenosti, ki je naposled povzročila, da je tudi sam prijel za pero. ${ }^{6}$

Kljub temu, da si je Enej Silvij Piccolomini naročil svoj izvod Aristotelove Politike, je v pismu 21. julija 1453 zapel hvalo Platonu z znamenitimi besedami o padcu Bizanca:

Itaque mansit usque in hanc diem vetuste sapientie apud Constantinopolim monumentum, ac velut ibi domicilium litterarum esset, nemo Latinorum satis videri doctus poterat, nisi Constantinopoli per tempus studuisset. Quodque florente Roma doctrinarum nomen habuerunt Athene, id nostra tempestate videbatur Constantinopolis obtinere. Inde nobis Plato redditus, inde Aristotelis, Demostenis, Xenophontis, Tuchididis, Basilii, Dionisii, Origenis et aliorum multa Latinis opera diebus nostris manifestata sunt, multa quoque in futurum manifestanda sperabamus. At nunc vincentibus Turchis et omnia possidentibus, que Greca potentia tenuit, actum esse de litteris Grecis arbitror. Nunquam mea sententia major Graeco nomini jactura quam modo contigit.

In tako je spomenik antični modrosti ostal v Konstantinoplu vse do današnjih dni, kot bi bila tam nekakšna domovina učenosti. Nihče od Latincev po mojem ne more biti videti zares učen, če ni vsaj nekaj časa študiral v Konstantinoplu. Zdi se, da ima danes Konstantinopel takšen pomen za znanje, kot so ga imele Atene, ko je cvetel Rim. Odtod nam je bil povrnjen Platon, odtod so se dela Aristotela, Demostena, Ksenofonta, Tukidida, Bazilija, Dionizija, Origena in mnogih drugih razodela $v$ latinščini in upamo, da nam bo v prihodnosti povrnjenih še veliko takih del. Vendar se sedaj, ob zmago- 
vitem turškem polaščanju vsega, kar je grška književnost dosegla, sprašujem, kaj bo z grško pismenostjo. Po mojem mnenju grštvo ni nikdar utrpelo večje škode kakor danes. ${ }^{7}$

Nikolaju Kuzanskemu je Piccolomini tedaj v pismu izrazil obžalovanje nad padcem Konstantinopla, ${ }^{8}$ ki ga je enačil z napačno interpretacijo antičnih modrecev, »z drugo smrtjo Homerja, Menandra, Pindarja in drugih slovitih pesnikov « ${ }^{9}$ ter drugo smrtjo Platona (»secunda mors ista Homero est, secundus Platonis obitus $«){ }^{10}$ Piccolominiju, ki je bil na neki način po rodu in izobrazbi Florentinec, je bilo čedalje bolj jasno, da so bile Firence grški pismenosti veliko bolj naklonjene kakor Rim, v katerem so še vedno gojili kanonično cerkveno miselnost. Kot papež Pij II. je zavestno združeval grški nauk s krščanskim sporočilom. Med njegovimi pismi je mogoče najti tudi dialoško zasnovano hvalnico Homerju. ${ }^{11}$

V svoji tretjeosebni avtobiografiji Komentarji je nicejskega škofa in kardinala Bessariona papež Pij II. večkrat omenjal kot enega redkih, ki so ga spodbujali v želji po boguvšečnosti in ga prosili, naj še naprej vztraja v veri. Bessarion je s svojim navdušenjem pri pripravah na sveto vojno proti Turkom pridobil na stran Pija II. celo Benečane. ${ }^{12}$ Vse omenjeno kaže, da se je grško znanje s pomočjo latinskih intelektualcev prenašalo v italijanske dežele, kjer se je na ta način tudi ohranjalo, deloma pa prikazuje tudi težavno politično-zgodovinsko situacijo, ki je od padca Konstantinopla in sklenitve florentinske unije postajala vedno bolj zapletena in ki se po smrti papeža Pija II. ni razrešila ali umirila. Morda bi bilo mogoče šteti kardinala Bessariona za idejnega ohranjevalca Piccolominijeve težnje po ohranitvi celostne podobe evropskega krščanstva, saj se je Bessarion po besedah Pija II. »srčno zavzel za stvar «. ${ }^{13} \mathrm{~S}$ svojo grško usmerjeno filološko dejavnostjo, ki se je odražala predvsem v veliki pozornosti do rokopisov, si je Bessarion zlasti po smrti papeža Pija II. in po letu 1468 , ko je svoje rokopise podaril Benetkam, resnično prizadeval za vzpostavitev nekakšnega »drugega Bizanca» na Zahodu. ${ }^{14}$ Aeneas, Accept Pius, 311.

8 Prim. Izbicki, »Introduction (From Private Person to Posterity)«, 49.

9 Izbicki, Reject Aeneas, Accept Pius, 313.

10 Prim. Geanokoplos, Byzantine East and Latin West, 111, op. 114.

11 Verdière, Essai sur Aeneas Sylvius Piccolomini, 138.

12 Verdière, Essai sur Aeneas Sylvius Piccolomini, 145.

13 Pius II, Commentaries, 13.

14 Harlfinger, Graecogermania, 21. 
Maksim Grek se je rodil kot Mihael Trivolis v grškomakedonskem mestu Arta (blizu današnje meje z Albanijo) okoli leta 1470, šest let po smrti papeža Pija II. leta 1464 . Kljub temu, da je bil deležen odlične domače izobrazbe, saj je bil njegov bližnji sorodnik (po vsej verjetnosti stric) Demetrij Trivolis ${ }^{15}$ bibliofil in znan zbiralec knjig in rokopisov ter je imel tudi dejavne stike s tedanjimi grškimi intelektualci, je Mihael odšel v severno Italijo, da bi svoje znanje še izpopolnil. V Italijo je potoval prek Krfa in Krete ter po vsej verjetnosti tudi prek hrvaških otokov.

Že v Arti in na poti v Italijo se je torej pobliže seznanil s humanisti, ki so bili le malo pred tem neposredno povezani z usodo Eneja Silvija Piccolominija. Sem sodijo še zlasti učenci in nasledniki kardinala Bessariona, ki je bil prijatelj in zaščitnik Demetrija Trivolisa in za katerega je slednji prepisal več grških rokopisov, med katerimi sta bili tudi Odiseja in Plotinove Eneade. ${ }^{16} \mathrm{~V}$ osebni knjižnici Demetrija Trivolisa, ki je bila sestavljena iz grških primerkov in iz lastnih prepisov, se je Mihael Trivolis prvič srečal z Iannosom Laskarisom, svojim bodočim učiteljem filologije. Laskaris je maja ali junija leta 1491 obiskal Demetrija Trivolisa, iščoč knjige za osebno knjižnico Lorenza Medičejskega. ${ }^{17} \mathrm{~V}$ Laskarisovem pismu Demetriju Halkondilu najdemo seznam knjig iz knjižnice Demetrija Trivolisa, ${ }^{18} \mathrm{ki}$ je med osemindvajsetimi knjigami vseboval tudi nekatere redke izvode vodilnih grških neoplatonistov. V Trivolisovi knjižnici je bil tudi izvod Porfirijevega dela Prolegomena iz 12. stoletja, pa Deksipov komentar k Aristotelovim Kategorijam, Heraklitove Alegorije, Temistijeve Razprave, komentarji k različnim knjigam Aristotela (denimo komentar k Prvi analitiki, pripisan Štefanu Aleksandrijskemu; in komentar Domnina iz Larise k Aristotelovemu delu O sofističnih ovržbah). ${ }^{19}$ Kot eno prvih knjig lastne knjižnice si je Trivolis že leta 1460 pridobil Platonovega Timaja, prepisanega na $\mathrm{Krfu},{ }^{20}$ kar je sovpadlo z obdobjem, ko je Tomaž Paleolog pred turškim napadom s svojo družino ubežal iz Mistre na Krf. Kakor je bila usoda rodbine Trivolis povezana s poslednjim Paleologom, tako je njegov klic na pomoč, naslovljen na Albance, opisoval tudi papež Pij II. v svoji avto-

Denissoff, Maxim le Grec et l'Occident, 83; 121.

Denissoff, Maxim le Grec et l'Occident, 123-124.

Denissoff, Maxim le Grec et l'Occident, 126.

Legrand, Bibliographie hellénique ou description raisonnée des ouvrages publiés en grec par des Grecs aux XVe et XVIe siècle, 322-324.

Denissoff, Maxim le Grec et l'Occident, 128.

Denissoff, Maxim le Grec et l'Occident, 123. 
biografiji. ${ }^{21}$ Prvega junija leta 1472 se je zgodila zaroka med hčerko Tomaža Paleologa Zoi-Sofijo in Ivanom III., moskovskim velikim knezom. Princesa je utelešala tudi upe grških emigrantov, še posebej up svojega učitelja Bessariona, ki se je nadejal osvoboditve grške domovine s strani Slovanov. Odisejo iz Trivolisove knjižnice je leta 1469 naročil Demetriju Trivolisu prepisati Bessarion, ${ }^{22}$ izvirnik te knjige pa je Trivolis odstopil ogrskemu kralju Matiju Korvinu. Tudi v to je bil vpleten papež Pij II., ${ }^{23}$ saj je bil Korvin tesno povezan z zadnjo načrtovano pomorsko bitko (»križarsko vojno«) proti Turkom, katere vodja je bil v celoti, idejno in v praksi, papež Pij II. Kardinal Bessarion, ki ga je v poslednjih letih svojega življenja papež Pij II. imel za skoraj edinega somišljenika in zvestega učenca, tako predstavlja nazorno presečišče tako miselnih kot realno-biografskih vzporednic med primerjavo duhovnega obzorja obeh protagonistov te razprave, saj jo opravičuje s skupnim virom grško-latinske učenosti.

Mihael Trivolis je $\mathrm{z}$ Laskarisom ob prepisovanju rokopisov sodeloval še pri urejanju besedil, pri njihovem prevajanju iz grščine v latinščino in pri pripravi grško-latinskih slovarjev. Prepisal je med drugim tudi Strabonovo Geografijo, ${ }^{24}$ ki jo je papež Pij II. vpletel v svoje avtobiografske Komentarje. Z navezavo na beneško ozemlje je denimo takole premišljeval o Ogleju: »Strabon v teritorij Benečije ne vključuje Ogleja, čeprav ga obliva ista jadranska plima, ki se zliva nad reko Nadižo. ${ }^{25}$ Njegove besede bi lahko pojasnili s papeževim zanimanjem za renesančne korografične študije italijanskih historiografov in kartografov, ${ }^{26}$ ki so v svojih delih obravnavali zgodovino od antike do tedanjega časa ter so posebno pozornost namenili Rimu in zgodnjemu krščanstvu (npr. Flavio Biondo, Leon Battista Alberti, Bartolomeo Platina). Res pa je tudi, da se je Pij II. zanimal za historiografsko ozadje področja, ki mu je bil duhovno nadrejen in o katerem je mogel izvedeti kaj več iz različnih srednjeveških kronik.

Pius II, Commentaries, 2.3-4, 12-13.

Trivolis je Odisejo prepisal v Rimu in jo opremil z notico, da je kopija nastala »med kardinalatom prečastitega Bessariona, Grka po rodu, z dostojanstvom škofa Sabinov in konstantinopelskega patriarha«; Denissoff, Maxim le Grec et l'Occident, 123, 127, op. 1, 133.

3 Henry, Études plotiniennes 1, 211.

4 Speranzi, »Michele Trivoli e Giano Lascari«, 276.

Pius II, Commentaries, 101-102.

Hay in Law, Italy in the Age of the Renaissance, 1380-1530, 5-6. 
V Laskarisovem florentinskem stanovanju je Mihael Trivolis leta 1492 spoznal Alda Manuzia. ${ }^{27}$ Po tistem, ko je 15. oktobra 1495 Karel VIII. prečkal Alpe, je Laskaris odpotoval v Francijo. Odtlej je bil Trivolis v Firencah precej negotov; vedno bolj je postajal pozoren na javne pridige $s$ kritiko cerkvene oblasti iz ust nazorsko radikalnega dominikanca Girolama Savonarole, ki je ostro nastopil proti oporečnosti tedanje cerkvene prakse. Približno štiri leta, do leta 1498, je trajala vedno večja duhovna prevlada, ki jo je imel Savonarola nad Florentinci. ${ }^{28}$ Štiri leta po usmrtitvi Savonarole, se je Mihael Trivolis leta 1502 odločil vstopiti v florentinski dominikanski samostan San Marco, vendar se ni odločil za posvetitev v meniha, ampak je ostal novic. ${ }^{29}$ Zdi se, da je Mihael našel duhovni mir zgolj $\mathrm{v}$ delu v Aldovi beneški tiskarni, kot je o tem pisal iz Firenc Scipionu Karteromahu, 21. aprila leta 1503 ali 1504:

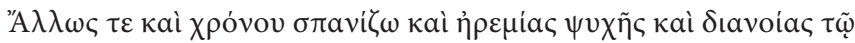

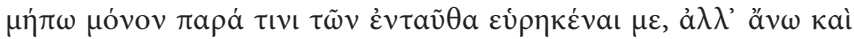

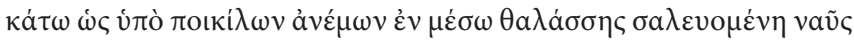

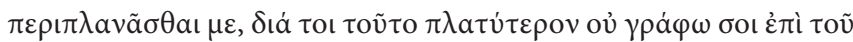

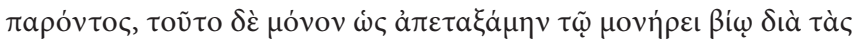

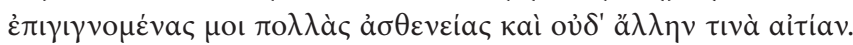

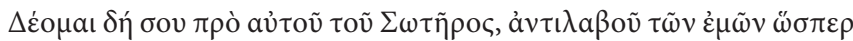

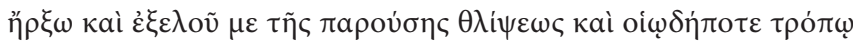

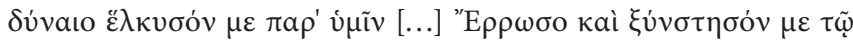
$\chi \rho \eta \sigma \tau \tilde{\omega}$ ” $\mathrm{A} \lambda \delta \omega$.

Poleg tega nimam niti časa niti miru v duši in umu, ne samo zato, ker ne bi našel ničesar pri nikomer od tukajšnjih, ampak tudi zato, ker me premetava na vse strani kakor ladjo, ki jo spremenljivi vetrovi pretresajo na odprtem morju. Zato ti tudi ne pišem ničesar več o dogajanju, le to, da sem se odpovedal meniškemu življenju zaradi mnogih bolezni, ki me pestijo, in ne zaradi česa drugega. Prosim te pred podobo samega Odrešenika, prevzemi moja dela, kot si to na nek način že začel, reši me te moje sedanje stiske in me spravi k vam, na kakršenkoli način že [...] Bodi zdrav in me priporoči cenjenemu Aldu. ${ }^{30}$ 
Za Mihaela Trivolisa je bilo torej pomembno, da je vzdrževal stike z Aldom Manutijem, saj je prek njega ohranjal tudi lastno knjižno dejavnost, poleg tega je včasih morda dobil v dar izvode lastnih knjig. Dvakrat je tudi bival na gradu Mirandola pri Giovanniju Picu della Mirandola, kjer je poučeval grščino njegovega nečaka, Gianfrancesca della Mirandola, in mu pomagal pri prevodu anonimnega traktata De monarchia Dei iz grščine v latinščino. ${ }^{31} \mathrm{Od}$ tam je Mihael napisal tudi štiri pisma Ioannosu Grigoropulosu, kretskemu intelektualcu, ki ni bil le privrženec aristotelizma, ampak se je zavzemal tudi za obnovljeno vrednotenje Platonove filozofije. Njuna korespondenca pa priča še o pomenu, ki ga je ukvarjanje s knjigami in rokopisi imelo za duhovno napajanje Mihaela Trivolisa. Marca leta 1500 je na rob pisma, ki ga je poslal v Benetke, zapisal:

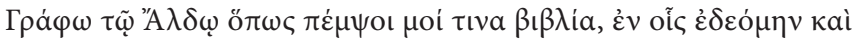

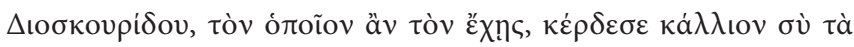

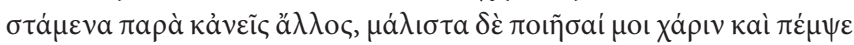

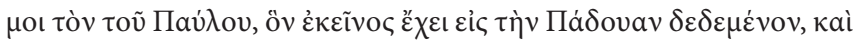

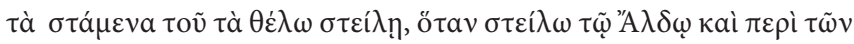
å $\lambda \lambda \omega \nu \beta \iota \beta \lambda i \omega v$.

Pisal sem tudi Aldu, da bi mi poslal nekaj knjig, med drugim sem prosil za Dioskorida. Če ga imaš, potem je najbolje, da za to poskrbiš ti; najbolje od vsega bi bilo, če bi me razveselil in mi poslal tisti izvod, ki ga je Pavel $^{32}$ zvezal v Padovi; denar zanj bom poslal, ko ga bom Aldu tudi za ostale knjige. ${ }^{33}$

Že tedaj je bil Mihael Trivolis kritičen do Aristotelove filozofije, s čimer je vplival tudi na Gianfrancesca della Mirandola. V Italiji bi njegovo, pogojno rečeno, naklonjenost do antične filozofije lahko opredelili kot delno prevzetje platonizma iz Mistre, katerega predstavnik je bil kardinal Bessarion, ter nekaterih pogledov učencev Gemista Pletona. ${ }^{34}$ Tudi v moskovski Rusiji je bil - kot Maksim Grek - vedno odprt za vrednotenje Platona, saj je mnoge svoje spi-

Denissoff, Maxim le Grec et l'Occident, 231. Identiteta »knjigovezca Pavla iz Padove« do danes še ni pojasnjena; prim. Fonkič, "Predislovie«, v: Grek, Sočinenija 1, 97, op. 10.

Grek, Sočinenija 1, 96-97.

Denissoff, Maxim le Grec et l'Occident, 122-123. 
se začenjal s trditvijo, da velja pripisati »prvenstvo med zunanjimi modreci« prav Platonu, ki naj bi po njegovih besedah predstavljal »začetek vseh milosti «. ${ }^{35}$

Leta 1503 je v Mihaelu Trivolisu dozorela odločitev, da Italijo zapusti. Vrnil se je v Grčijo, tokrat na sveto goro Atos, kjer je vstopil v samostan Vatoped in postal pravoslavni menih Maksim. Tam je nadaljeval svoje delo z rokopisi. Njegova renesančna izobrazba $\mathrm{v}$ Vatopedu pa je bila zelo cenjena ( $\mathrm{v}$ nasprotju s prezirom do tega znanja, na katerega je naletel pozneje v moskovski Rusiji), saj so mu zaupali prepis redkega starega dokumenta iz 12. stoletja, odločilnega pri dodelitvi samostanskih posesti. ${ }^{36} \mathrm{~V}$ tistem obdobju je postal učenec in spremljevalec konstantinopelskega patriarha Nifonta II., s katerim sta skupaj opravljala pravoslavne misijone tudi izven Atosa, najpogosteje na ozemljih Moldo-Vlahije. Med takimi srečanji je latinščina takrat predstavljala ustaljen jezik diplomacije in kulturne enakovrednosti. Za patriarha Nifonta je menih Maksim napisal nekaj epigramov, denimo ob smrti glasbenika Manuela Korintskega in ob smrti patriarha Nifonta II. Za razširjenje takšnih biografskih epigramov po evropskih dvorih pa je bil v letih pred tem zaslužen prav Piccolomini. ${ }^{37}$

Leta 1516 je bil menih Maksim Vatopedski kot jezikovno nadarjen in razgledan intelektualec izbran za prevajalca in redaktorja svetih knjig, za katerega je v pismu prosil ruski veliki knez Vasilij III. Odpotoval je v moskovsko Rusijo, kjer so ga začeli klicati Maksim Grek. Takoj po prihodu 5. marca leta 1518 je najprej prevedel Apostol (Apostolska dela s pismi) s komentarji, nato pa Psalter s komentarji, prvi tak zbir psalmov z obširnimi patrističnimi razlagami $\mathrm{v}$ moskovski Rusiji dotlej. Med drugim pa se je med njegovimi zgodnjimi prevodi našel tudi prevod spisa papeža Pija II. z naslovom »Povest o turškem zavzetju Konstantinopla«. Ni povsem jasno, ali besedilo nemara ni pismo Pija II., naslovljeno na Mehmeda II. Zmagovalca, v katerem ga je papež vabil, da bi sprejel krščansko vero. Vsebina obeh tekstov je sorodna, vendar besedilo rokopisa govori v prid prvi interpretaciji. Prevod spisa papeža Pija II. v starocerkvenoslovanščino, kot ga je oskrbel Maksim Grek, se začenja z naslednjimi besedami: »Sin Amuratov, Mehmed, se je zdrznil v svojih mislih in se vprašal, kako bi lahko osvojil Konstantinopel. Za svojo slavo med Turki si je zaželel, da bi to mesto kristjanov

Grek, Sočinenija 1, 151-152.

Fonkič, »Dve paleografičeskie zametki k izdaniju aktov Kastamonita (novye avtografy Ioanna Evgenika i Maksima Greka)«, 57-59.

Simoniti, Humanizem na Slovenskem, 24-27. 
videl pod svojo oblastjo in vladavino. ${ }^{38}$ Pomembno pa se zdi, da je Pijevo podoživljanje okoliščin in krščanske ogroženosti močno ustrezalo Maksimovi osveščenosti o turški nevarnosti, ki se je širila po Evropi v času, ko je bil tam tudi sam. Vredno je zato izpostaviti, da je Maksim Grek v svoji renesančni teologiji razumel tudi sleherni prevod kot tisto človekovo delo, ki mora potekati pod budno pozornostjo in neprestanim klicanjem Svetega Duha.

\section{LITERARNO-TEORETSKE VZPOREDNICE (IDEJNO-NAZORSKA RAVEN)}

Čeprav bi lahko primerjali veliko tem in gledišč v nazorih obravnavanih avtorjev, se ta raziskava osredotoča na jezikovne, teološke in literarne vzporednice. Izpostaviti je mogoče specifično rabo določenih izrazov, ki jo je najpogosteje mogoče pripisati teološkim formulacijam. Priča o zavedanju jezikovnih problemov, ki morejo vznikniti v procesu sporazumevanja in ki lahko vodijo do nesporazumov.

Enej Silvij Piccolomini se je sprva šolal pri vaškem duhovniku. Naučil se je latinščine, ki je imela določene skladenjske posebnosti, ${ }^{39}$ od katerih ni odstopal. Takšno latinščino je pisal vse življenje. Še več, Piccolominijev individualni jezik je pozneje zaslovel zaradi posebno izbrušenega sloga. ${ }^{40}$ Prav tako velja, da si je Maksim Grek izoblikoval svojstveno obliko starocerkvenoslovanščine, ki bi jo lahko opredelili kot njegov osebni idiolekt. ${ }^{41}$

Leta 1525 je bil namreč v moskovski Rusiji na cerkvenem zboru Maksim Grek obtožen krivoverskih napak pri prevodih in popravkih v ruskih liturgičnih rokopisih. Obsodili so ga na pripor v najtežjih pogojih - zaprli so ga v samostansko temnico, mu prepovedali obiskovanje maše in prejemanje obhajila, niso mu dovolili ne brati ne pisati, vzeli so mu njegove grške knjige, poleg tega ni smel z nikomer govoriti. ${ }^{42}$ Leta 1531 , na drugem sojenju, so se obtožbe obnovile in dopolnile; leta 1536 je bil njegov pripor blažen le do te mere, da mu je bilo dovoljeno pisati. Odtlej je napisal veliko količino spisov, 143-144v. Izbicki, »Introduction (From Private Person to Posterity)«, 10.

40 Hay, Italy in the Age of the Renaissance 1380-1530, 126.

41 Več o tem Zajc, "Some Notes on the Life and Works of Maxim the Greek (Michael Trivolis, cca 1470-Maksim Grek, 1555/1556), 2: Maxim the Greek's Slavic Idiolect«, 375-382.

42 Sudnye spiski Maksima Greka i Isaka Sobaki, ur. N. N. Pokrovski, 55. 
v katerih je med drugim tudi opravičeval svoj pravoslavni nazor in svoje ravnanje še zlasti pri delu z ruskimi svetimi knjigami. V spisu Odgovor o popravljanju ruskih knjig je zapisal:

Но о сущемъ убо въ мнъ и съблюдаемом исповъдании православныа въры доволна вам въ увърение писаннаа мною в ливель моего отвђта. А яко не порчю священныа книгы, яко же клевещут мя враждующеи ми всуе, нъ прильжнъ и съ всякым вниманиемъ и Божиимъ страхом и правым разумом исправливаю ихъ, в них же растлъвашеся ово убо от преписующих ихъ ненаученых сущих и неискусных в разумъ и хытрости грамотикыи стъи, ово же от самъх исперва сътворъших книжныи превод приснопамятных мужеи, речет бо ся истина, есть негдъ неполно разумъвших силу еллиньскых ръчеи, и сего ради далече истинны отпадоша.

O svoji veri in upoštevanju pravoslavne veroizpovedi sem vam dovolj napisal že v svojem odgovoru v obliki livela. Ker sam ne kvarim svetih knjig, kakor me klevetajo tisti, ki me ne marajo, ampak $z$ veliko pozornostjo in $z$ božjim strahom in resničnim razumom popravljam v njih tisto, kar so nepravilno zapisali prepisovalci, ker niso bili dovolj podučeni in so bili neizkušeni v razumevanju in nevešči svete gramatike. Ali pa so že prvi spoštovani prevajalci nepravilno prevedli, ker niso povsem razumeli osnovnega besedila ali niso dovolj obvladali grškega jezika in so zato močno zgrešili resničen pomen. ${ }^{43}$

Na začetku tega odlomka je izraz (»livel«), ki ga lahko razložimo z znanjem latinščine in $\mathrm{z}$ mladostno izobrazbo, kakršne je bil Trivolis deležen v severni Italiji. Latinski izraz libellus je bil tedaj tudi literarni žanr, ožje vezan na Piccolominijev humanistični krog. Leta 1436 se je prav na podlagi spisa Libellus apologeticus kardinala Giuliana Cesarinija, v katerem je avtor evropske vladarje opozarjal na radikalne težnje baselskega cerkvenega zbora, Piccolomini začel nagibati k drugačnemu doseganju cerkvene enotnosti, saj ni več odobraval politike koncila in je bil vedno bolj naklonjen papežu. Iz tega izraza je mogoče sklepati, da je Maksim Grek s takim izrazom poimenoval niz apologetskih spisov, ki jih je napisal v obliki odgovorov (»moj odgovor v obliki livela«) kot odziv na krivične obtožbe ruskih oblasti, da bi opravičil svojo nedolžnost. ${ }^{44}$ Pozneje je v pismih 
metropolitu Makariju (ok. 1547-1548) Maksim Grek še zaostril svoj zagovor z opozarjanjem na cerkvene razmere v Rusiji, saj je v »desetih zvezkih«, ki jih je imenoval Libellus, pisal o različnih dogmah, o meniških praksah (na primer o kesanju, o postenju, o molitvah) in o nestrinjanju z islamsko vero. ${ }^{45} \mathrm{Zdi}$ se celo, da se je Maksim Grek navezoval na tisti del svoje mladosti, ki jo je nazorsko odobraval, ter na čas, ko se je srečal z meniško-asketskim delom renesančne Italije, ko je bil v dobrih prijateljskih odnosih s kamaldulskim menihom Pietrom Candidom Leucheimonom. ${ }^{46}$ Omenjeni izraz najdemo tudi v naslovu spisa pri beneškem kamaldulskem menihu Paolu Giustinianiju. V spisu ta ni kritiziral samo tedanjih cerkvenih razmer in papeštva, temveč tudi ozko filološko ukvarjanje z jezikom; ob tem je pozival k boljšemu poznavanju Svetega pisma in krščanske teologije. ${ }^{47}$ Vredno je še omeniti, da je Piccolomini med letoma 1435 in 1438 napisal tudi traktat $\mathrm{z}$ naslovom Libellus dialogorum de auctoritate generalium Concilii et gestis basileensium (1440), posvečen rektorju univerze v Kölnu, prežet s svetopisemskimi citati in referencami iz cerkvene zgodovine. V njem je Piccolomini izrazil svoje radikalne nazore glede cerkvenih očetov in nadvlade koncila nad papežem, do odstranitve Evgena IV. in izvolitve Feliksa V. Gre za dialoški traktat med Stefanom Caccia in Nikolajem Kuzanskim, ki se dopolnjuje $\mathrm{z}$ dialogi med Piccolominijem in Martinom LeFrancom. Besedilo, polno referenc na antične avtorje, spominja na poročilo o pogovoru med prijatelji, ki namenoma zagovarjajo različna stališča. ${ }^{48}$ Pomemben za razvoj renesančne književnosti, še zlasti pa za starorusko literaturo, kjer naj oblika dialoga (pred njim) ne bi obstajala, je tudi dialoški spis Maksima Greka z naslovom »Pogovor med dušo in umom", v katerem ima vodilno besedo um. V spisu je avtor postavil temelje meniške teologije, zasnovane na osebnem sprejemanju svetopisemskega jezika.

V pismih Eneja Silvija Piccolominija lahko opazimo, da je začel katoličane imenovati z izrazom »Latinci«, ki ima v njegovih spisih vedno nekoliko ironičen prizvok. V pismu Juanu de Carvajalu, znanem kot »Komentarji posledic koncila v Baslu ali Popravljena zgodovina koncila«, je v jubilejnem letu 1450 še kot Enej Silvij Piccolomini zapisal: 
Sic ad Grecos due Latinorum classes misse sunt inter sese dissidentes; quasi non satis esset, inter Grecam Latinamque ecclesiam discidium fore, nisi et Latini scinderentur. Ridiculum profecto et multis antea seculis inauditum, ut qui divisi essent Latini ad unionem Grecos invitarent. Ridere Greci Latinam sapientiam potuerunt, qui morbum herentem cordi negligerent, digitorum egritudinem maximo studio curarent.

Dve ladjevji Latincev, ki si drug drugemu nasprotujejo in se ne razumejo, sta bili poslani Grkom. Kakor bi ne bilo dovolj, da obstaja nesoglasje med grškimi in latinskimi cerkvami, so zdaj razdeljeni še Latinci. Smešno je misliti, da bi med seboj razdeljeni Latinci vabili Grke v unijo, in več stoletij ni bilo govora o tem. Grki so se lahko smejali modrosti Latincev, ko puščajo ob strani bolezen, ki že stiska srce, ter se namesto tega skrbno posvečajo bolečini v prstih. ${ }^{49}$

Razlago izraza »Latinci« bi lahko poiskali v polemičnih spisih Maksima Greka, ki je v Moskvi, v svojem prvem obdobju, s tem izrazom nedvoumno imenoval tiste, ki niso upoštevali pravoslavne teologije. V prvi vrsti je opozarjal na teološko sporen latinski dodatek $\mathrm{k}$ veroizpovedi, filioque, ki je na zahodu prehajal v uradno veljavo od 9. stoletja (od Karla Velikega) naprej..$^{50}$ Maksim Grek je vztrajal, da je s tem "heretičnim besednim priveskom « porušeno ravnovesje imenovanja treh hipostaz Svete Trojice. Za višek spekulativnosti Latincev je imel tedanje zgledovanje po filozofskih, predvsem aristotelovskih nazorih. Po tistem, ko se je soočil z jezikovnimi napakami v ruskih bogoslužnih knjigah, zaradi česar je bil na cerkvenem zboru leta 1525 in 1531 obtožen herezije in obsojen na samostansko ječo, je začenjal med ruskimi cerkvenimi možmi prepoznavati tudi odsotnost slovnične zavesti in nepoznavanje filozofskih osnov, nepravilno prevajanje grških virov in splošno nepoznavanje antične retorike, poetike in cerkvenih očetov. Zato je poudarjal, da je poleg nasprotovanja Latincem polemično pisal tudi proti zgodnjekrščanskim herezijam (arijancem, makedonijcem, evtihijcem in nestorijancem) ter proti tedanjim renesančnim ločinam, v prvi vrsti proti »judovalcem« (rus. židovstvujušie«), proti armenskemu nauku ter proti islamski veri. Povedno je, da je papež Pij II. omenjal enake zgodnjekrščanske ločine v pismu 26. aprila 1563 in se pri tem opiral 
na njihovo nasprotovanje osnovnim načelom človeškosti. ${ }^{51}$ Podobno se je tudi še kot Piccolomini teološko prepiral s husiti. Zato se zdi, da je Maksim Grek pisal prav proti tistim herezijam, s katerimi se je srečal že v renesančni Italiji in ki so ogrožale kanonično krščansko vero. Oba teološko usmerjena pisca pa sta se očitno globoko zavedala težavnosti islama in njegove nevarnosti za krščanstvo, ko se je po padcu Bizanca v maju leta 1453 začel močno širiti po osrednji Evropi. Piccolomini o padcu Konstantinopla piše v pismu 21. julija 1453, torej dober mesec dni po porazu. V besedilu je razviden piščev odpor do prihajajočega nasilja, pa tudi do teološko dvoumnih in zavajajočih invencij:

Surgunt nove secte, fiunt novi litterarum caracteres, surgunt ingenia diversa, que omnia tollunt; quicquid ante se fuit, ineptum putant, ecce nunc Turchi litterarum et Grecarum et Latinarum hostes, ut suis ineptiis locum faciant, nullum librum alienum esse sinunt. Hi nunc Constantinopoli capta quis dubitet incendio quevis scriptorum monimenta concedentur. Nunc ergo et Homero et Pindaro et Menandro et omnibus illustrioribus poetis secunda mors erit. Nunc Grecorum philosophorum ultimus patebit interitus. Restabit aliquid lucis apud Latinos, at fateor neque id erit diuturnum, nisi mitiori nos oculo deus ex alto respexerit [...] Multum est, quod Tatari Turchique tenent citra Thanaim et Hellespontum ...

Dvigajo se nove ločine; pojavila se je nova abeceda. Dvigajo se drugačne vrednote, ki naj bi nadomestile vse obstoječe; mislijo, da vse, kar je bilo prej, nima več nikakršne vrednosti. Glej, zdaj so Turki, sovražniki grških in latinskih črk, sklenili narediti prostor za lastne neumnosti ter ne trpijo nobene tuje knjige. Kdo bi zdaj, ko je Konstantinopel zavzet, še dvomil, da je vsak spomin na tiste pisce predan plamenom? Zdaj bo torej nastopila druga smrt Homerja, Pindarja, Menandra in drugih slovitih pesnikov. Zdaj bo prišel končni propad grških filozofov. Med Latinci bo sicer ostalo nekaj malega svetlobe, vendar, priznajmo, tudi ta ne bo dolgo trajala, če se Bog na nas ne ozre z blažjim pogledom [...] Tatari in Turki držijo večino področja med Donom in Helespontom. ${ }^{52}$ 


\section{MENIŠKA POLEMIKA Z RENESANČNIMI NAZORI (LITERARNO-TEOLOŠKA RAVEN)}

Med florentinskimi intelektualci, s katerimi je imel Mihael Trivolis dejavne stike (Cristoforo Landino, Marsilio Ficino, Angelo Poliziano), so nanj največji vtis naredile pridige dominikanca Girolama Savonarole, o katerem je pozneje kot Maksim Grek napisal obširen spis z naslovom Povest, strašna in vredna spominjanja. V tem besedilu naj bi se posredno dotaknil usode treh Florentincev, Domenica Buonvicinija, Marsilia Ficina in Giovannija Pica della Mirandola. ${ }^{53}$ Napisal je tudi niz polemičnih spisov, usmerjenih proti astrologiji, verjetno je poznal Savonarolov Traktat proti astrologiji, ki ga je slednji posvetil Picu della Mirandola. Savonarola se je navezoval na Picovo delo Disputationes adversus astrologiam divinatricem, ki ga je posmrtno, leto dni po Picovi smrti na rokah Savonarole, ${ }^{54}$ izdal njegov nečak Gianfrancesco della Mirandola. Med Giovannijem Picom della Mirandola in Girolamom Savonarolo je opaziti vzajemen nazorski vpliv. Če so nazori učenega dominikanca močno vplivali na Picovo filozofijo v poslednjih mesecih življenja, je zato mogoče trditi, da je omenjeni Savonarolov spis nastajal ob branju Picovih besedil. Obe deli odražata srž tedanjih pogledov na astrologijo, ${ }^{55}$ kot so se tedaj oblikovali v florentinski duhovni eliti in so radikalno izpostavljali nasprotje med astrologijo in božjim navdihom. Čeprav je šlo za zgledovanje tudi pri Picu della Mirandola, ${ }^{56}$ se zdi, da je bil v resnici pogled Maksima Greka na renesančnem ozadju še radikalnejši. Ni priznaval nikakršnega pomena, kaj šele dokazljivega vpliva zvezd in planetov na življenje vernika, čigar usodo je v celoti prepuščal volji krščanskega Boga. Kajti kljub temu, da filozofija Pica della Mirandola upošteva svetopisemsko sporočilo, je v njegovem spisu $O$ človekovem dostojanstvu še vedno tudi jasno izraženo upoštevanje, celo čaščenje, planetov in zvezd:

Tam blande vocati, tam benigniter invitati, alatis pedibus quasi terrestres Mercurii, in beatissimae amplexus matris evolantes, optata pace perfruemur [...] Citemus et Mosem ipsum a sacrosanctae et ineffabilis intelligentiae fontana plenitudine, unde angeli suo necta-

4 Martines, Scourge and Fire, 219. tivy tščaščihjsja zvezdozreniem predricati o buduščih i o samovlastii čelovekom' 
re inebriantur, paulo deminutum. Audiemus venerandum iudicem nobis in deserta huius corporis solitudine habitantibus leges sic edicentem: Qui polluti adhuc morali indigent, cum plebe habitent extra tabernaculum sub divo [...] Quo forte fit ut et Caldei in eius genesi qui philosophus sit futurus, illud desiderent, ut Mars et Mercurium triquetro aspectu conspiciat.

Na tako vabljiv klic, na tako blagohotno povabilo, bomo z okriljenimi nogami kakor zemeljski Merkurji poleteli v objem presrečne matere in užili zaželeni mir [...] Pokličimo za pričo celo samega Mojzesa, ki stoji le malo niže od vira polnosti presvete, neizrekljive umnosti, s katere nektarjem se opijanjajo angeli. Slišali bomo častitljivega sodnika, kako nam, ki živimo zapuščeni v pustinji svojih teles, oznanja zakone: tisti, ki so še nečisti in ne potrebujejo poduka moralne filozofije, naj prebivajo skupaj z ljudstvom izven šotora. [...] In morda ravno zaradi tega tudi Kaldejci zahtevajo, da ob rojstvu tistega, ki naj bi nekoč postal filozof, Mars gleda Merkurja v trikotnem soju. ${ }^{57}$

Omemba moralne filozofije v tem odlomku nemara vodi k Piccolominiju, saj je obveljal za enega od začetnikov renesančnega moralnega pisanja. ${ }^{58}$ A ost Maksima Greka je bila naperjena proti »ljudskim lažnivcem, prerokovalcem iz zvezd, ki vse ljudi odganjajo od razumske presoje in od vladanja bistvu vsega ustvarjenega, od Tistega, ki vidi prihodnost vseh ljudi - s tem ko s Fortuno, to pomeni s srečo, in planeti in z zodiakom, zelo nepobožno pojasnjujejo upravljanje sveta ${ }^{59}$ Utemeljeno je misliti, da se je Maksim Grek navezoval na mit o Fortuni, ki je postal med Florentinci priljubljen še zlasti leta $1494,{ }^{60}$ ko je tam bival kot Mihael Trivolis in so intelektualci kazali precejšnje zanimanje za epikurejski nauk. Zato je pozneje v svojih spisih Maksim obsojal sleherno zanašanje na zmotljiva človeška dognanja in prisegal na presojo (individualnega posameznikovega!) razuma: „Če bomo izgubili razum, bomo kakor Kaldejci, muslimani in Latinci, ki se zanašajo na kolo sreče. " ${ }^{61}$ To trditev je ponavljal v več inačicah in jo navezoval tudi na privržence epikurejstva, ${ }^{62}$ med vekovem dostojanstvu, 14-15; 23; prevedel Brane Senegačnik.

58 Harlfinger, Graecogermania, 213.

59 Moskva, Rossijsskaja gosudarstvennaja biblioteka (RGB): Mss. Rum. 264, 1. 12 r.

60 Dictionnaire de la Renaissance italienne, 137.

61 Moskva, RGB: Mss. Rum. 264, 1. 27 r.

62 Moskva, RGB: Mss. Rum. 264, 1. 28 r. 
katerimi je izpostavil Nemce (»Germane») in Latince (»Lahe»), ki so verjeli v mit o Fortuni. Tega mita Maksim Grek ni povezoval samo $\mathrm{z}$ delovanjem zlih duhov (»besov«), ${ }^{63}$ temveč je njegov izvor iskal v starejših naukih Hebrejcev, Egipčanov, Sircev in Arabcev, ki so verjeli v astrološke napovedi. ${ }^{64}$ Njihova stališča je imel za bogoborska. ${ }^{65}$

$\mathrm{V}$ tem smislu omemba kaldejskega nauka v Devetsto tezah Pica della Mirandola, v poglavju »Šest sodb po mnenju kaldejskih teologov«, ne dosega nazorske strogosti Maksima Greka, saj temelji na številski, kaldejski, nemara celo kabalski predpostavki o nekem vedenju. ${ }^{66}$ Prav tako bi humanistična prepričanja Eneja Silvija Piccolominija nemara lažje opredelili z njegovim verovanjem v vpliv planetov in zvezd na človeško usodo. A zdi se verjetno, da se je čedalje bolj zavedal varljivosti takšnih napovedi in sugestij, saj je ločeval med tistimi, ki napovedujejo posameznikovo usodo ob rojstvu, in tistimi, ki napovedujejo tekoče dogodke, kot je to natančno opredelil v avtobiografiji Komentarji. ${ }^{67}$ Omenjeno pa zgolj nazorno prikazuje tedanjo intelektualno vzdušje med renesančnimi humanisti, med katerimi je astrologija veljala za eno od pomembnih znanstvenih ved. $^{68}$

Ob upoštevanju navedenega je lažje razumeti rastoče nasprotovanje astrologiji v delih Maksima Greka, ki je s svojim posebnim razumevanjem bibličnega jezika in celote Svetega pisma za edine verodostojne štel svetopisemske prerokbe. Skliceval se je zlasti na starozavezne preroke in psalme. Posebno pozornost je posvečal bibličnim pesmim, ki so predstavljale osnovo bogoslužnih hvalnic in so sledile po branju 150 psalmov. Te pesmi je prevedel dvakrat. Prvič z interpretativnimi komentarji vzhodnih in zahodnih cerkvenih očetov $^{69}$ leta 1520 , drugič pa štiri leta pred smrtjo, leta 1552, v Liturgičnem psaltru, kjer je omenjene hvalnice podal v jezikovno prečiščenem prevodu. Na verodostojnost teh pesmi se je pogosto skliceval tudi v svojih spisih in jih uporabljal kot del teološke argumentacije. Tak pogled, ki ima svoj smisel v liturgično-teološkem razumevan-

63 Moskva, RGB: Mss. Rum. 264, 1. $16 \mathrm{v}$.

64 Moskva, RGB: Mss. Rum. 264, 1. 14 v-1. 15 r.

65 Moskva, RGB: Mss. Rum. 264, 1. 17 r.

66 Pico della Mirandola, Devjat'sot tezisov - Conclusiones sive theses DCCCC, 129.

67 Pius II, Commentaries, 65.

68 Dictionnaire de la Renaissance italienne, 40.

69 Če naštejemo le nekatere $\mathrm{z}$ nazivi, kot so poimenovani v rokopisu (Moskva, Državni zgodovinski muzej (GIM): Šhuk. 4): Teodor Kirski, Gregor Nazianški, Didim, Evzebij iz Cezareje, Janez Krizostom, Akvila, Atanazij Veliki, Vasilij Kapadokijski, škof Asterij, Viktor Prezbiter, Evdoksij Filozof, Teodor Iraklij, Nikola Prezbiter, Diodor, Kiril Aleksandrijski, Isihij, Teodor Antiohijski. 
ju kristologije, se je razširil z razcvetom bizantinske himnografije, še posebej z bogoslužnimi hvalnicami v čast Bogorodici ${ }^{70}$ in v teoloških komentarjih liturgične službe, »božje liturgije«. ${ }^{71}$ Še podrobneje se je Maksim Grek posvečal tretji liturgični pesmi, "pesmi prerokinje Ane«, Samuelove matere (1 Sam 2,1-10), ki jo je štel za neposredno pričevanje Svetega Duha Tolažnika (Parakleta). ${ }^{72}$ To pesem je razumel kot potrditev tega, kako nesmiselno je zaupanje $\mathrm{v}$ astrološke napovedi. Vendar pesmi ni interpretiral s pomočjo znanih patrističnih komentarjev, ampak je predlagal povsem lastno fatalistično-teološko razumevanje. Poleg številnih protiastroloških spisov je tri spise naslovil O tretji pesmi prerokinje Ane ali Proti astrologom, ki predstavljajo različice razmisleka o božji previdnosti. V spisu z naslovom $V$ pismu nekemu menihu, nekdanjemu igumenu, o nemški skušnjavi, Fortuni in njenem kolesu, je zapisal:

\begin{abstract}
Потщися убо, Бога ради потщися, отскочи таковыя нъмецкыа прелести // и исповъдуи прямъ и чисть съ богодухновеными Давидомъ и пророчицею Анною, глаголющими сице явъ и бес хытрословиа всякого: »Господь убожит и богатит, смиряетъ и высит, възставляеть от земли нища и от гноища въздвизает убогащ. Чесо ради, рци намъ, о священная пророчице? »Да посадит его, рече, съ силными людии и престолом славным насльдника.«
\end{abstract}

Pokesaj se, pokesaj se zaradi Boga, in odskoči od take nemške skušnjave // in izpoveduj čisto in neposredno z Davidom in Ano, ki sta bila od Boga navdihnjena: »Gospod nekoga pahne v revščino in nameni drugemu bogastvo, nekoga pokori in drugega poviša, od zemlje dviga ubogega in iz blata potegne siromašnega.« Čemu le, povej nam, sveta prerokinja? »Da bi ga posadil skupaj s krepkimi na prestol, kjer ga bodo slavili prihodnji rodovi. ${ }^{73}$

Tak teološki razmislek, ki temelji na bibličnih sholijah, sicer pa izhaja iz osebnega doživljanja bogoslužja, je bil lasten ključnemu bizantinskemu teologu šestega stoletja Maksimu Spoznavalcu, ${ }^{74}$ katerega meniško ime je Maksim Grek prejel ob vstopu v atoški sa-

71 Več o tem Bornert, Les commentaires byzantins de la divine liturgie de VIIe au XVe siècle, 1966.

72 Moskva, RGB: Mss. Rum. 264, 1. 16.

73 Grek, Sočinenija 2, 305.

74 Bornert, Les commentaires byzantins de la divine liturgie, 117-123. 
mostan Vatoped leta 1506. V Anini pesmi je prepoznaval resnico, da so vse človeške usode odvisne samo od božje volje in da za vsa slehernikova ponižanja ali povišanja skrbi zgolj najvišja krščanska instanca. Značilno zanj je sklicevanje v obliki aluzije na krščanskega Boga v Sveti Trojici. ${ }^{75}$ Nekje zapiše: »Mi, blagoverni kristjani, izpovedujemo Kristusa Boga, ki ureja in vodi vse. In ne s človeškimi pomisleki in nasveti, ampak z božjim razmislekom in z njegovimi potmi, ki jih ni moč docela izkusiti, so ustvarjena in usmerjana vsa človeška bitja. ${ }^{76} \mathrm{~S}$ tem prepričanjem je Maksim Grek utemeljeval specifično strogost svojega pravoslavnega nazora, ki je izvirala iz vere v božji razum, to bistveno vsebnost človeške duše, ki veruje. Tudi papež Pij II. se je v svoji strogosti v četrti knjigi avtobiografskih Komentarjev skliceval na besede preroka Ezekiela (Ezk 33,11), ko je zapisal: »Cerkev je pravzaprav blažja, saj grešniku ne želi smrti, ampak njegovo prenovo. ${ }^{77}$ Maksim Grek pa razumljivo ni zavračal koristnosti astroloških - bolje rečeno astronomskih - napovedi glede naravnih pojavov, ki so lahko koristni pri vremenu, razmerah na morju, poljedelstvu itd. ${ }^{78} \mathrm{~V}$ spisu $\mathrm{z}$ naslovom Proti vedeževalski astrologiji pravi:

Услышимъ смыслено преподобнаго отца Иоанна Дамаскына и отступим, молю, прочее обладавшыа нами звъздочетцовъ прелести. Глаголетъ же сицъ явъ божественыи онъ отець и учитель: „Еллини убо звъздами сими, солнцем же и луною, въстоку и западу разумъша вся, яже о нас строитися; мы же глаголемъ, яко знамениа от них бываютъ дожду и бездожию, // студеньству же и теплоть, мокроть и сухоть и вътром, а наших дълъ никако же; мы же самовластни бывше Съдътелем, властеле есме своих дълъ.

Poslušajmo smiselnost besed svetega očeta Janeza Damaščana in zapustimo, rotim vas, skušnjave prerokovalcev iz zvezd, ki so začeli vse obvladovati. Takole jasno govori ta božanski oče in učitelj: »Heleni so vendar z zvezdami, soncem, luno in z vzhodom in zahodom razumeli vse, kar nas je ustvarilo. Mi pa pravimo, da so ta zna- 
menja dobra za dež in sušno obdobje, // za hlad in toploto, za vlago in sušo in veter, nikakor pa ne za naša dejanja. Mi smo samostojni in imamo svojo voljo, da sebi vladamo, vladarji smo lastnih dejanj.. ${ }^{79}$

Maksim Grek, ki je prisegal na nespoznatnost ali »globino nedosegljivih božjih usod " in volje Najvišjega, ${ }^{80}$ je v verujočem človeku videl obdarjenost s pobožnostjo in $\mathrm{z}$ občudovanjem "nebesne filozofije «. ${ }^{81}$ Nasprotje temu po njegovem predstavlja tisto, kar meji na živalskost in na nerazumnost. Zdi se, da je v takem pogledu mogoče prepoznati gledišče, ki so ga širili učeni menihi renesančne Italije. ${ }^{82}$ Podobno je papež Pij II. razmišljal v svojem odzivu na nasvete slehernikov. Tako je spregovoril o sebi, v retorični tretjeosebni obliki v svojih avtobiografskih Komentarjih:

Risit consilium pontifex, iubensque Romanos accedere ac sellam subire: »Super aspidem, « inquit, »et basiliscum ambulabis, et conculcabis leonem et draconem." Quod propheticum et alias saepe impletum est, et nunc implebitur. Nam quae immanior fera est quam homo? Quae bestia peiora facit, quam homo? Verum animal mutabile homo est, et saevissima saepe mitescunt ingenia.

Papež se je nasmehnil njihovemu nasvetu in je, ko je predlagal zbližanje z Rimljani, navedel mesto: „Čez leva in gada boš stopal, poteptal boš mladega leva in morsko pošast. « ${ }^{83}$ Ta prerokba se je v preteklosti že pogosto uresničila in bo izpolnjena tudi danes. Katera zver je bolj divja od človeka? Katera divja žival naredi več slabega? Pa vendar je človek spremenljiva žival in še tako okrutna narava se pogosto omehča. ${ }^{84}$

Maksim Grek je imel sklicevanje na astrološke napovedi za neposredno zavračanje delovanja Svetega Duha in pomena krsta, za polemiziranje $z$ dogmo Svete Trojice, ${ }^{85}$ za nasprotovanje môči križanega Odrešenika. Našteto je bilo zanj primerljivo z neupoštevanjem osnovnih Kristusovih zapovedi. ${ }^{86}$ Za slednje je našel dokaze celo

Grek, Sočinenija 2, 154.

Moskva, RGB: Mss. Rum. 264, 1. 17 v.

Moskva, RGB: Mss. Rum. 264, 1. 15.

Hay, Italy in the Age of the Renaissance 1380-1530, 302.

Ps 91,13.

Pius II, Commentaries, 365.

R., Rum. 264, 1. 15.

L. $24 \mathrm{~V}$. 
pri antičnih mislecih; v smešenju vere v mit o Fortuni se je skliceval na Platona in Kebeta. ${ }^{87}$ Temelj njegovega besednega boja pa je predstavljala Biblija: Mojzes in Izaija, ${ }^{88}$ psalmi, Pavlovi pismi Efežanom (Ef 5,5-6) in Kološanom ( $\mathrm{Kol} 2,8$ ). Na podlagi Pavla je osnoval lastno hierarhijo znanja. Ločeval je zunanje znanje (filozofija, retorika, logika, matematika, geometrija, dialektika, astronomija) in notranje znanje (vse asketsko in meniško vedenje, ki ga vernik pridobi z notranjo kontemplacijo, branjem Svetega pisma in svetih spisov ter $\mathrm{z}$ molitvijo). Notranje vedenje je poimenoval »teologija Gospoda Jezusa Kristusa ${ }^{89}$ Podobno ločevanje znanj na zunanje in notranje je najti pri prvi generaciji grške diaspore (Teodor iz Gaze, Konstantin Laskaris, Manuel Hrizoloras, Demetrij Halkondil, Maksim Planudes) ${ }^{90}$ in drugih tedanjih bizantinskih filologih, ki so pisali slovnice in $\mathrm{z}$ njimi povezane filozofske spise, namenjene tujcem, ki niso znali grško. Maksim Grek je nasprotoval omenjenim naukom predvsem zato, ker zanje ni našel svetopisemske podlage ter je v njih videl zgolj človeško spekulativnost. Poudarjal je moč kesanja in vere od krsta naprej; le to lahko pripomore k odrešenju duše. V dialoškem spisu Pogovor med dušo in umom je zapisal, kako je najpomembnejša lastnost človeške duše, da je »besedna in nesmrtna«, ${ }^{91} \mathrm{~s}$ čimer je želel povedati, da je duša doumljiva in sama najbolj dovzetna za besede in racionalno oblikovane premise. Človeka je pojmoval kot obdarjenega s sposobnostjo za doumevanje božjega razuma, kot bitje, ki lahko svoj um bistri zgolj v čuječnosti in pozorni molitvi. Zdi se, da je mogel tak nazor delno povzeti po antropološki hierarhiji, lastni teološki misli Maksima Spoznavalca. V spisu Ne zvezde ali kolo Fortune, previdnost božja vodi vse človeško je Maksim Grek zapisal:

Якоже и божественыи Максим Исповъдникъ премудръише и благочестивъ учит сице нъкако, глаголя: »[...] по естеству же ума дълание есть, да сущаа въ насъ словеснаа чясть повинуется всегда божественому слову, и да владъетъ над сущею в нас безсловесною чястию.«

87 L. $14-15 \mathrm{~V}$.

88 L. $25 \mathrm{v}$.

89 Grek, Sočinenija 1, 194.

90 Robins, The Byzantine Grammarians, 201.

91 Grek, Sočinenija 2, 253. 
Kakor nas najbolj modro in pobožno uči božanski Maksim Spoznavalec, rekoč: »[...] Po bistvu uma je naše delovanje, da se v nas navzoči besedni del vedno podreja božanski besedi ter da vlada nebesednemu delu, ki je tudi prisoten v nas. $\ll^{92}$

V psalmih je Maksim Grek našel odgovor, da vse v njih napovedane nesreče, požari in vojne pravzaprav pomenijo prihodnje (oziroma zanj tedanje) islamske napade na krščansko vero. ${ }^{93}$ Papež Pij II. nemara prav zaradi pogostega sklicevanja na svetopisemske besede za mnoge poznejše teoretike humanizma predstavlja uganko, saj se ne sklada s podobo tipičnega renesančnega individuuma. ${ }^{94}$ Čeprav je bila tudi za mnoge humaniste in protestantske reformatorje Biblija osnovno sredstvo, s katerim so pozivali k duhovni obnovi človeka, ${ }^{95}$ je bilo obema obravnavanima avtorjema skupno predvsem zavedanje nevarnosti, ki je tedaj pretila krščanski veri v osrednji Evropi. Pisanje obeh je treba zato razumeti v luči tedanjega nazorskega ozadja, ki ga predstavlja renesančno zavzemanje za uveljavitev dogme o nesmrtnosti duše. Papež Pij II. je namreč svoje prizadevanje za uresničenje križarske vojne proti Turkom razumel kot najtesnejšo, čeprav posredno, zahtevo po zaščiti vseh krščanskih duš, kot je sam zapisal v Komentarjih:

Messis quidem multa, operarii autem pauci. Messis nostra, fratres, animarum salus est; ager, in quo metimus, Ecclesia, quam vestro consilio regendam accepimus: hanc contra Turchos et infideles alios tueri debemus, ex hac tribulos et malas herbas, hoc est haereses et pravos mores, extirpare cogimur.

Žetev je velika, delavcev pa malo. Naša žetev, bratje, je odrešitev duš; polje, kjer žanjemo, je Cerkev, ki jo moramo po vašem sklepu voditi. Cerkev je tista, ki jo moramo braniti pred Turki in neverniki; iz Cerkve moramo izvleči trnje in zastrupljene osti - krivoverstva in blazna ravnanja. ${ }^{96}$

Grek, Sočinenija 2, 155.

Moskva, RGB: Mss. Rum. 264, 1. 26 v.

Izbicki, »Introduction (From Private Person to Posterity) «, 7-9.

Delumeau, La civilisation de la renaissance, 145-146.

Pius II, Commentaries, 227. 


\section{ZAKLJUČEK}

Morda ni naključje, da se niz spisov Maksima Greka začenja s prizorom, ob katerem avtor navaja novozavezne besede iz Jakobovega pisma (Jak 1,17) s prizorom slehernika, na katerega se zliva božanska svetloba. S tem je upodobil pravico človeka do vidne luči, ki jo je Maksim razumel kot jasno potrdilo Kristusove milosti. Enačil jo je s svetopisemsko svetlobo nebesnega svoda, kakor jo je doumel iz psalma 18 , ki ga je tudi obširno interpretiral. ${ }^{97} \mathrm{~V}$ njegovem sistemu pravoslavne teologije je prav element element zrenja ali videnja, ki ga je delno povzel po nazoru Janeza Damaščana, predstavljal posredniško bistvo ikonografsko in teološko predstavljene hierarhije Svete Trojice. Zato je bila za njegovo pravoslavno teologijo značilna svojevrstna vizualno doumljiva podoba Božjega Sina, ki jo lahko razumemo kot neposreden duhovni sad branja svetopisemskih besedil in pisanja teoloških spisov. Sintetično združevanje tako avtobiografskih kot teološko-liturgičnih prvin je prisotno v skoraj vseh Maksimovih spisih, tudi v besedilu z nazornim naslovom Odgovor o popravljanju ruskih knjig, pa tudi proti tistim, ki govorijo, da je Gospodovo telo po vstajenju od mrtvih postalo neopisljivo, v katerem je omenjeno videnje opisljive podobe Božjega Sina tudi argumentirano:

Аз же предложилъ бых вам убо на болшее извъщение глаголемаа мною к вам писанаа блаженымъ Иоанном Дамаскыном въ 33 главъ, ими же богословьствует нарочить и явьственъише о плотьском смотрьнии Единороднаго. Нъ понеже различно перепорчена есть от преписующих у вас священныа книгы, не смълъ предложити вам предобрыа ръчи Его, акы зъло неразумна и неустроена зримы. Богу же поспЂшествующу, предложу вамъ и та, егда греческую книгу получю, аще Господь благоволить.

Jaz bi vam vse podrobno razložil na podlagi spisov blaženega Janeza Damaščana, kot ta piše v 33. poglavju, kjer teološko povsem jasno razsoja o telesnem zrenju Edinorojenega. A dokler so besedila v vaših svetih knjigah na različne načine poneverjena, vam tega nisem smel ponuditi, čeprav je to dobro branje, ki celo nerazumne in neredne usmerja $\mathrm{k}$ Bogu. Pa vam bom predlagal tudi to, ko bom dobil grško knjigo, če mi bo to Bog blagovolil nakloniti. ${ }^{98}$ 
Res so Maksimu Greku ob prvem sojenju leta 1525 odvzeli tudi njegove grške knjige, med katerimi je bil tudi izvod Janeza Damaščana. S takšnim razumevanjem Svetega pisma, še posebej s kristološko interpretacijo Stare zaveze, je Maksim Grek odsev notranje svetlobe razumel zgolj kot uverturo v osebno molitev, kot iniciacijski trenutek, ki pomeni začetek poglobljenega pisanja. Asketska usmerjenost je bila zanj korak k ozaveščanju notranje svetlobe kot znanilke božje Modrosti. Prav z avtobiografskim značajem svojih spisov pa je bistveno zaznamoval svoje ustvarjanje $\mathrm{z}$ renesančnim humanizmom, v katerem se je avtobiografski žanr uveljavil kot eden najbolj izvirnih.

Primer renesančne avtobiografije, ${ }^{99}$ skupaj s sledovi srednjeveškega patosa $\mathrm{v}$ tretjeosebni naraciji in s prepletanjem tako posvetnih kot ožje cerkvenih tem, je predstavljalo prav avtobiografsko delo Komentarji Eneja Silvija Piccolominija, ki ga je začel pisati, ko je bil okronan za papeža Pija II., in ga je končal na predvečer svoje smrti. V svojih Komentarjih je Piccolomini o poslanstvu, ki ga je sprejel s papeškim nazivom, zapisal, da se mu je razodelo kot svoboda, za katero je verjel, da more biti prek papeške službe dostopna tudi vsem ostalim verujočim. ${ }^{100}$ Piccolominijeva odločitev, da po mnogih letih $\mathrm{v}$ vlogi cesarjevega tajnika in dvornega pesnika stopi na posvečeno pot, je dozorela leta 1446 . V pismu 13. avgusta leta 1447 je zapisal, da se je odločil za meništvo. ${ }^{101}$ Najprej je služil kot nižji diakon, nato osem mesecev kot diakon. V pismu Giovanniju Campisiju je omenil, kako se je odločal med dvema oblikama krščanskega življenja, med laiško in kleriško, in slednjič izbral red svetega Petra. ${ }^{102}$ Leta 1447 je postal tržaški škof, leta 1450 je bil imenovan še za sienskega škofa, 19. avgusta 1458 je bil izvoljen za papeža. Njegova dejanja in besedila potrjujejo, da je pojmoval posameznika kot nekoga, ki ima pravico, da se po letih posvetnih življenjskih izkušenj prostovoljno odloči za življenje v veri, ki naj naposled predstavlja njegov izraz - tudi jezikovni.

Dejavno teološko prepletanje zahodne in vzhodne krščanske misli, pridobljeno tako v procesu intelektualnega napredovanja kot tudi v osebni molitvi, je obema obravnavanima avtorjema omogočilo poseben pogled na posameznika, ki je bil v času, ko je bilo krščanstvo na preizkušnji, poklican prevzeti odgovornost (in krivdo) za pot k odrešenju vseh krščanskih duš.

99 Dictionnaire de la Renaissance italienne, 41-42.

100 Pius II, Commentaries, 353.

101 Izbicki, Reject Aeneas, Accept Pius, 278.

102 Izbicki, Reject Aeneas, Accept Pius, 232-233. 


\section{BIBLIOGRAFIJA}

\section{Rokopisi}

Moskva, Državna knjižnica (RGB), rokopisni oddelek, zb. Rum. 264.

Moskva, Državni zgodovinski muzej (GIM), rokopisni oddelek, zb. Sin. 791.

Moskva, Državni zgodovinski muzej (GIM), rokopisni oddelek, zb. Shuk. 4.

\section{Sekundarni viri}

Bornert, René. Les commentaires byzantins de la divine liturgie de VIIe au XVe siècle. Pariz: Institut français d'études byzantines, 1966.

Delumeau, Jean. La civilisation de la renaissance. Pariz: Arthaud, 1984.

Denissoff, Élie. Maxime le Grec et l'Occident: Contribution à l'histoire de la pensée religieuse et philosophique de Michel Trivolis. Paris: Bibliothèque de l'Université, 1943.

Dictionnaire de la Renaissance italienne. 2. izd. Ur. J. R. Hale in Patrick de Mauries. Pariz: L'univers d'art, 1992.

Fonkič, B. L. »Predislovie«. V: Maksim Grek: Sočinenija. T. 1, 83-84, opombe. Moskva: Indrik, 2008.

__. "Dve paleografičeskie zametki k izdaniju aktov Kastamonita (novye avtografy Ioanna Evgenika i Maksima Greka)«. V: Grečeskie rukopisi i dokumenty v Rossii v XVI - načale XVIII v., 57-59. Moskva: Indrik, 2003.

Garin, Eugenio, ur. Giovanni Pico della Mirandola: Oratio de hominis dignitate. Pordenone: Edizioni studio tesi, 1994.

Garzaniti, Marcello. »Svjaščennoe pisanie i auctoritates u Maksima Greka«. Trudy Otdela Drevnerusskoj Literatury. Ur. O. V. Pančenko. T. 64. IRLI. Sankt Peterburg: Rostok, 2016. 32-46.

Geanakoplos, Deno J. Byzantine East and Latin West. Oxford: Archon Books, 1978. Gigante, Claudio. »Introduzione, E Profetta e le stelle«. V: G. Savonarola: Contro gli Astrologi. Rim: Salerno Editrice, 2000.

Grek, Maksim. Sočinenija 1. Moskva: Indrik, 2008.

—_. Sočinenija 2. Moskva: Rukopisnye pamjatniki drevnej Rusi, 2014.

Harlfinger, Dieter. Graecogermania: Griechischstudien deutscher Humanisten. New York: Acta Humaniora, 1989.

Hay, Denys, in John Law. Italy in the Age of the Renaissance 1380-1530. London: Longman, 1989.

Henry, Paul. Études plotiniennes I: Les états du textes de Plotin. Bruselj: Museum Lessianum, 1939-1941.

Ivanov, A. V. Literaturnoe nasledie Maksima Greka. Leningrad: Nauka, 1969. 
Izbicki, Thomas M. »Introduction (From Private Person to Posterity)«. V: Reject Aeneas, Accept Pius: Selected Letters of Aeneas Sylvius Piccolomini (Pope Pius II), 2-57, ur. in prev. Thomas M. Izbicki, Gerald Christianson in Philip Krey. Washington: Catholic University of America Press, 2006.

_- Gerald Christianson in Philip Krey, ur. Reject Aeneas, Accept Pius: Selected Letters of Aeneas Sylvius Piccolomini (Pope Pius II). Washington: The Catholic University of America Press, 2006.

Legrand, Émile. Bibliographie hellenique ou description raisonne des ouvrages publiés en grec par des Grecs aux XVe et XVIe siècle. Pariz, 1885.

Martines, Lauro. Scourge and Fire: Savonarola and Renaissance Italy. London: Pimlico, 2009.

Messerve, Margaret, in Marcello Simonetta, ur. Pius II: Commentaries 2. Books III-IV. The I Tatti Renaissanse Library. Firence: Harvard University Press, 2007.

Mirandola, Pico della. Devjat'sot tezisov - Conclusiones sive theses DCCCC. Moskva: Izd. Russkoj hristianskoj gumanitarnoj akademii, 2010.

Pokrovski, N. N. ur. Sudnye spiski Maksima Greka i Isaka Sobaki. Moskva: Tipografija Gau, 1971.

Robins, Robert H. The Byzantine Grammarians. Trends in Linguistics. Berlin, New York: Mouton de Gruyter, 1993.

Romoli, Francesca. »'Trattato contra li astrologi' Girolamo Savonarola i 'Slovo protivy tščaščihjsja zvezdozreniem predricati o buduščih i o samovlastii čelovekom' Maksima Greka: Opyt sopostavitel'nogo analiza. V: Wiener Slavistischer Jahrbuch (Neue Folge), 3, 1-17. Dunaj, 2015.

Salaville, Sévérien. Liturgies orientales. Pariz: Librarie Bloud\&Gay, 1932.

Senegačnik, Brane, prev. Giovanni Pico della Mirandola: O človekovem dostojanstvu, spremna beseda Igor Škamperle. Ljubljana: Tretji dan, 1997.

Siecinski, Edward A. The Filioque: History of a Doctrinal Controversy. Oxford: Oxford University Press, 2010.

Sinicyna, N. V. »Rannee tvorčestvo Maksima Greka«. V: Maksim Grek: Sočinenija. T. 1, 9-15. Moskva: Indrik, 2008.

—_. Maksim Grek v Rossii. Moskva: Nauka, 1977.

Speranzi, David. »Michele Trivoli e Giano Lascari: Appunti su copisti e manoscritti greci tra Corfù e Firenze«. Studi Slavistici 7 (2010): 263-297.

Totaro, Luigi. »Il pio Enea: un papa umanista«. Siena - dalle origini alla fine della repubblica. Ur. Roberto Barzanti, Giuliano Catoni, Mario De Gregorio, 371-383. Firence: Edizioni ALSABA, Siena, 1995.

Verdière, Charles Hippolyte. Essai sur Aeneas Sylvius Piccolomini. Pariz: Joubert, Librarie-Editeur, 1843.

Wolkan, Rudolf, ur. Der Briefwechsel des Eneas Silvius Piccolomini. Fontes rerum Austriacarum. Dunaj: Kaiserliche Akademie der Wissenschaften, 1909-1918. 
Zajc, Neža. »Some Notes on the Life and Works of Maxim the Greek (Michael Trivolis, ca 1470 - Maksim Grek, 1555/1556): Part 2: Maxim the Greek's Slavic Idiolect«. Scrinium 12 (2016): 375-382.

\section{POVZETEK}

Prispevek prek primerjalne analize biografskih dokumentov, nazorov, literarnih in teoloških del obravnava dva kompleksna renesančna načina za razumevanje humanističnega individuuma, kot se odražata v delih svetega Maksima Greka in Eneja Silvija Piccolominija. Primerjava dveh teologov, ki sta precejšen del življenja preživela v stiku z renesančno mislijo, pokaže, kako je slednja zaznamovala tudi njuna teološka sistema ter zaostrila njuno ortodoksnost v nepopuščanju tedaj aktualnemu antropocentrizmu. Obema avtorjema so skupne: osebna raba jezika (idiolekt); odprto in ustvarjalno sprejemanje tako vzhodnega kot tudi zahodnega krščanstva; nasprotovanje krivoverskim ločinam; poudarjen kristološki teocentrizem; zavedanje ogroženosti krščanskega sveta; avtobiografskost njunih del. Prav v združevanju vzhodnih in zahodnih krščanskih elementov ter v izpostavljenem in prepoznavno osebnem interpretiranju svetopisemskega sporočila je mogoče utemeljiti podobnost primerjanih nazorov. Povečana avtobiografskost njunih spisov priča o močni vezi $\mathrm{z}$ renesančnim humanizmom.

KLJUČNE BESEDE: humanisti, božanske modrosti, teološki nazor, posameznikov osebni jezik, pisma, avtobiografija, astrologija 
AENEAS SILVIUS PICCOLOMINI AND SAINT MAXIMUS THE GREEK - THE CONCEPT OF HUMANISTIC INDIVIDUUM

\section{ABSTRACT}

The paper carries out a comparative analysis of the biographical documents, theological and literary writings, as well as worldviews of two complex Renaissance concepts of the humanistic individuum, as seen in the works of Aeneas Silvius Piccolomini and Saint Maximus the Greek. A comparison between the two theologians, both marked by the Italian Renaissance, shows how their experience imbued their views with a specific orthodoxy and a distinct theocentrism. Both authors used their personal language, an idiolect; were active in their reception of Western and Eastern Christianity; confronted heretical teachings; and represented Christological theocentrism as well as an awareness that Christian civilization is under threat. Similarly, both employed an autobiographical tone in their respective writings. The synthesis and juxtaposition of Western and Eastern elements of Christianity in their works and a significant number of personally interpreted Biblical references that are otherwise very specific to Renaissance literature confirm the similarity of both writers' worldviews. Autobiographical characteristics of their works betray the specifically Renaissance context of their writings.

KEYWORDS: humanists, theological writings, idiolect, autobiography, letters, astrology 